\title{
Peran Pembimbing Konseling Islam dalam Menangulangi Konflik, Stres, Trauma dan Frustrasi
}

\author{
Eha Julaeha \\ Program Studi Bimbingan Konseling Islam, Fakultas Ushuluddin Adab dan Dakwah, \\ IAIN Syekh Nurjati Cirebon \\ eha.iaincirebon@gmail.com
}

\begin{abstract}
Abstrak
Pada dasarnya setiap manusia pasti tak pernah lepas dari konflik, stress, trauma bahkan frustasi. Baik yang disebabkan oleh faktor internal maupun eksternal. Halhal tersebut sangatlah lumrah. Karena manusia merupakan makhluk sosial. Yang bisa dikatakan selalu membutuhkan relasi dengan orang lain. Namun dalam menjalin relasi tersebut bisa menimbulkan suatu dampak, entah itu dampak positif maupun dampak negatif. Dampak positif seperti seseorang bisa lebih luas mengenal satu sama lain, mendapatkan wawasan yang baru, dan lain sebagainya. Sedangkan dampak negatifnya yaitu bisa menimbulkan permasalahan jika teijadi ketidakseimbangan dalam relasi tersebut. Dan dari masalah itulah akan muncul konflik yang mengakibatkan seseorang menjadi stress, trauma bahkan frustasi. Akan tetapi bukan berarti manusia harus takut akan permasalahan tersebut, lantas tidak ingin menjalin relasi dengan lingkungan disekitarnya. Karena permasalahan itu sudah merupakan hal yang selalu melekat dalam hidup manusia.
\end{abstract}

Kata Kunci: Pembimbing Konseling Islam; Stress; Trauma; Frustasi.

\section{PENDAHULUAN}

Sebuah hal yang lumrah setiap manusia tidak akan lepas atau terbelit dalam konflik, stress, trauma, dan frustasi. Hampir setiap manusia pernah mengalami konflik. Hal-hal lersbut bisa terjadi dengan berbagai macam hal baik itu dari internal maupun eksternal eksternal. Jurnal ini menjelaskan konsep serta faktor-faktor terjadinya konflik, stress, trauma, frustasi yang kemudian dijadikan bahan kajian dalam konsep bimbingan konseling islam. Karena secara keseluruhan beberapa hal tersbut dapat mengganggu psikis dan psikologi orang yang mengalaminya.

Dari hal tersebut setiap permasalahan perlu adanya bimbingan dalam upaya pemberian solusi atau nasehat untuk menyelesaikan masalah tersebut. Karena itu peran bimbingan konseling islam sangat membentu sekali dalam memberikan motivasi dan pemecahan masalah untuk terus menjalani hidup dalam berbagai kondisi atau keadaan 
apapun, hal ini sesua dengan pengertian Bimbingan konseling islam merupakan proses pemberian bantuan terhadap individu agar mampu hidup selaras dengan ketentuan dan petunjuk Allah, sehingga dapat mencapai kebahagiaan hidup di dunia dan akhirat. Proses pemberian motivasi dan konsling ini yang kemudian di rangkum menjadi konsep bimbingan konseling islam.

Dalam proses pelaksanaan bimbingan konseling tersebut terdapat faetor-faktor yang mempengaruhi berjalanannya proes konseling. Factor ini meliputi factor eksternal yang terdidir dari lingkungan fisik, tempat wawancara, penataan ruang, dsb.. ada juga factor internal yang terdiri dari pihak konseli yang harus termotivasiunluk mencari penyelesaian terhadap masalah yang sedang dihadapi.

\section{PEMBAHASAN}

\section{Konflik}

Konflik berasal dari kata kerja Latin conligere yang berarti saling memukul. Kats. B. And Lehner menjelaskan konflikmerupakan suatu keadaan yang menekankan karena adanya dua atau lebih pertentangan, dari keinginan-keinginan seseorang. Dalam diri manusia terdapat beberapa dorongan, keinginan yang saling bersaing untuk dipenuhi dan dipuaskan. Ada pula yang sling bertentangan, sehingga dalam waktu yang sama tidak dapat terpenuhi. Maka konflik dapat digolongkan menjadi :

1. Konflik atau pertentangan antara dua hal atau keadaan yang sama-sama diiginkan sehingga keduannya tak mungkin dipenuhi. Misalnya seorang gadis yang ingin dilamar oleh dua oang dalam waktu yang hampir bersamaan. Pemuda itu keduaduannya hampir mirip, sama- sama tampan bagi si gadis mereka memenuhi syarat sehingga gadis itu malah bingung menentukannya. Pada diri gadis itu terjadi konflik. Konflik i8ni sebenarnya mudah diadakan penyelesaian asalkan ada pilihan salah satu dan menolak salah satunya.

2. Konflik atau pertentangan antara satu hal. yaitu sisi satu diinginkan dan sisi yang lain tidak diinginkan. Keinginan yang satu mengambat atau menghalangi yang lain. Misalnya ada seorang yang pernah dirawat di rumah sakit karena mengalami sakit perut yang parah/dearhee. Setelah sembuh, ia ingin sekali makan rujak. Di samping ingin itu iappun takut kalau-kalu dearhee dan harus dirawat di rumah sakit lagi. Baginya makin besar keinginan maka rujak makin besar kekuatan sakit juga makin besar. Penyelesaian konflik ini asal ada yang berkepentingan mau meninggalkan atau mengagalkan apa yang disenangi atau menerima hal yang tak disenangi.

3. Konflik atau pertentangan antara dua hal yang sama-sama tak disenangi. Misalnya seorang prajurit yang berada di medan perang, bilamana maju atau menyerang terus ia akan mati karena dalam posisi yang menghawatirkan. Bila ia mundur atau lari, berarti ia menghianati sumpah prajurit serta takut kepada hukum militer. Hal ini berhubungan tak ada pilihan maka tinggal menyerah, waspada sebab keduannya tak dapat dihindari. 


\section{Dinamika konflik}

Dinamika Konflik Konflik adalah segala macam interaksi pertentangan atau antagonistik antara dua atau lebih pihak. Timbulnya konflik atau pertentangan dalam organisasi, merupakan suatu kelanjutan dari adanya komunikasi dan informasi yang tidak menemui sasarannya. Konflik dilatar belakangi oleh perbedaan ciri-ciri yang di bawa individu dalam suatu interaksi.

\section{Gejala-Gejala Konflik}

Gejala-gejala dari konflik ialah sebagai berikut.

1. Adanya komunikasi yang lemah. Hal ini terjadi karena keputusan yang diambil berdasarkan informasi yang salah. Dua kelompok (minimal) akan bergerak ke arah yang berlawanan berdasarkan permasalahan yang sama.

2. Adanya friksi antar pribadi. Hubungan antar individu sering kali berada dalam kelompok lain biasanya akan mempengaruhi kebiasaan kelompok tersebut sehingga ketika kembali kepada kelompoknya seringkah tanpa menyadari telah membawa gagasan atau kebiasaan kelompok lain. Dalam keadaan demikian maka akan mudah muncul konflik.Adanya permusuhan atau iri hati antar kelompok. Hal ini disebabkan karena adanya perlakuan dan sikap yang tidak adil dari pimpinan kepada bawahan. Baik secara individual atau secara kelompok.

3. Eskalasi arbritrasi. Semakin banyak kelompok yang berkonflik maka biasanya kelompok-kelompok ini akan dipaksa untuk melakukan arbritasi (jalan damai).

4. Adanya moral yang rendah. Orang yang mempunyai moral rendah seringkah menampakkan kondibandingkan bersahabat.

5. Kinerja orang yang bermoral rendah cenderung kurang baik dan seringkah bertindak tanpa perhitungan yang cermat. Dalam keadaan demikian tidak menutup kemungkinan akan banyak muncul konflik.

6. Gejala konflik yang penulis deskripsikan tersebut merupakan indikasi akan munculnya sebuah konflik. Gejala konflik berbeda dengan penyebab terjadinya konflik, jika gejala konllik tidak mesti terjadi konflik maka penyebab konllik sudah pasti konflik itu terjadi. Terdapat heterogenitas penyebab konflik dalam masyarakat, masing- masing memiliki corak yang berbeda.

\section{Penyebab Konflik}

1. Perbedaan individu, yang meliputi perbedaan pendirian dan perasaan.

Setiap manusia adalah individu yang unik. Artinya, setiap orang memiliki pendirian dan perasaan yang berbeda-beda satu dengan lainnya. Perbedaan pendirian dan perasaan akan sesuatu hal atau lingkungan yang nyala ini dapat menjadi faktor penyebab konflik sosial, sebab dalam menjalani hubungan sosial, seseorang tidak selalu sejalan dengan kelompoknya. Misalnya, ketika berlangsung pentas musik di lingkungan pemukiman, tentu perasaan setiap warganya akan berbeda-beda. Ada yang merasa terganggu karena berisik, tetapi ada pula yang merasa terhibur. 
2. Perbedaan latar belakang kebudayaan sehingga membentuk pribadi- pribadi yang berbeda.

Seseorang sedikit banyak akan terpengaruh dengan pola-pola pemikiran dan pendirian kelompoknya. Pemikiran dan pendirian yang berbeda itu pada akhirnya akan menghasilkan perbedaan individu yang dapat memicu konflik.

3. Perbedaan kepentingan antara individu atau kelompok.

Manusia memiliki perasaan, pendirian maupun latar belakang kebudayaan yang berbeda. Oleh sebab itu, dalam waktu yang bersamaan, masing-masing orang atau kelompok memiliki kepentingan yang berbeda-beda. Kadang-kadang orang dapat melakukan hal yang sama, tetapi untuk tujuan yang berbeda-beda. Sebagai contoh, misalnya perbedaan kepentingan dalam hal pemanfaatan hutan. Para tokoh masyarakat menanggap hutan sebagai kekayaan budaya yang menjadi bagian dari kebudayaan mereka sehingga harus dijaga dan tidak boleh ditebang. Para petani menbang pohonpohon karena dianggap sebagai penghalang bagi mereka untuk membuat kebun atau ladang. Bagi para pengusaha kayu, pohon-pohon ditebang dan kemudian kayunya diekspor guna mendapatkan uang dan membuka pekerjaan. Sedangkan bagi pecinta lingkungan, hutan adalah bagian dari lingkungan sehingga harus dilestarikan.

Jelas terlihat ada perbedaan kepentingan antara satu kelompok dengan kelompok lainnya sehingga akan mendatangkan konflik sosial di masyarakat. Konflik akibat perbedaan kepentingan ini dapat pula menyangkut bidang politik, ekonomi, sosial, dan budaya. Begitu pula dapat terjadi antar kelompok atau antara kelompok dengan individu, misalnya konflik antara kelompok buruh dengan pengusaha yang terjadi karena perbedaan kepentingan di antara keduanya. Para buruh menginginkan upah yang memadai, sedangkan pengusaha menginginkan pendapatan yang besar untuk dinikmati sendiri dan memperbesar bidang serta volume usaha mereka.

4. Perubahan-perubahan nilai yang cepat dan mendadak dalam masyarakat.

Perubahan adalah sesuatu yang lazim dan wajar terjadi, tetapi jika perubahan itu berlangsung cepat atau bahkan mendadak, perubahan tersebut dapat memicu terjadinya konflik sosial. Misalnya, pada masyarakat pedesaan yang mengalami proses industrialisasi yang mendadak akan memunculkan konflik sosial sebab nilai-nilai lama pada masyarakat tradisional yang biasanya bercorak pertanian secara cepat berubah menjadi nilai-nilai masyarakat industri.

Nilai-nilai yang berubah itu seperti nilai kegotongroyongan berganti menjadi nilai kontrak kerja dengan upah yang disesuaikan menurut jenis pekerjaannya. Hubungan kekerabatan bergeser menjadi hubungan struktural yang disusun dalam organisasi formal perusahaan. Nilai-nilai kebersamaan berubah menjadi individualis dan nilai-nilai tentang pemanfaatan waktu yang cenderung tidak ketat berubah menjadi pembagian waktu yang tegas seperti jadwal kerja dan istirahat dalam dunia industri. Perubahan-perubahan ini, jika terjadi seara cepat atau mendadak, akan membuat kegoncangan proses-proses sosial di masyarakat, bahkan akan terjadi upaya penolakan 
terhadap semua bentuk perubahan karena dianggap mengacaukan tatanan kehiodupan masyarakat yang telah ada

\section{Akibat konflik}

Hasil dari sebuah konflik adalah sebagai berikut.

1. Meningkatkan solidaritas sesama anggota kelompok (ingruup) yang mengalami konflik dengan kelompok lain.

2. Keretakan hubungan antar kelompok yang bertikai.

3. Perubahan kepribadian pada individu, misalnya timbulnya rasa dendam, benci, saling curiga dll.

4. Kerusakan harta benda dan hilangnya jiwa manusia.

5. Dominasi bahkan penaklukan salah satu pihak yang terlibat dalam konflik.

Para pakar teori telah mengklaim bahwa pihak-pihak yang berkonflik dapat menghasilkan respon terhadap konflik menurut sebuah skema dua- dimensi; pengertian terhadap hasil tujuan kita dan pengertian terhadap hasil tujuan pihak lainnya. Skema ini akan menghasilkan hipotesa sebagai berikut.

1. Pengertian yang tinggi untuk hasil kedua belah pihak akan menghasilkan percobaan untuk mencari jalan keluar yang terbaik.

2. Pengertian yang tinggi untuk hasil kita sendiri hanya akan menghasilkan percobaan untuk "memenangkan" konflik.

3. Pengertian yang tinggi untuk hasil pihak lain hanya akan menghasilkan percobaan yang memberikan "kemenangan" konflik bagi pihak tersebut.

4. Tiada pengertian untuk kedua belah pihak akan menghasilkan percobaan untuk menghindari konflik.

\section{Stress}

Stress adalah bentuk ketegangan dari fisik, psikis, emosi maupun mental. Bentuk ketegangan ini mempengaruhi kinerja keseharian seseorang. Bahkan stress dapat membuat produktivitas menurun, rasa sakit dan gangguan-gangguan mental. Pada dasarnya, stress adalah sebuah bentuk ketegangan, baik fisik maupun mental. Sumber stress disebut dengan stressor dan ketegangan yang di akibatkan karena stress, disebut strain. Menurut Robbins (2001) stress juga dapat diartikan sebagai suatu kondisi yang menekan keadaan psikis seseorang dalam mencapai suatu kesempatan dimana untuk mencapai kesempatan tersebut terdapat batasan atau penghalang.

Dan apabila pengertian stress dikaitkan dengan penelitian ini maka stress itu sendiri adalah suatu kondisi yang mempengaruhi keadaan fisik atau psikis seseorang karena adanya tekanan dari dalam ataupun dari luar diri seseorang yang dapat mengganggu pelaksanaan kerja mereka. Menurut Woolfolk dan Richardson (1979) menyatakan bahwa adanya system kognitif, apresiasi stress menyebabkan segala peristiwa yang terjadi disekitar kita akan dihayati sebagai suatu stress berdasarkan arti atau interprestasi yang kita 
berikan terhadap peristiwa tersebut, dan bukan karena peristiwa itu sendiri.Karenanya dikatakan bahwa stress adalah suatu persepsi dari ancaman atau dari suatu bayangan akan adanya ketidaksenangan yang menggerakkan, menyiagakan atau mambuat aktif organisme. Sedangkan menurut Handoko (1997), stress adalah suatu kondisi ketegangan yang mempengaruhi emosi, proses berpikir dan kondisi seseorang. Stress yang terlalu besar dapat mengancam kemampuan seseorang untuk menghadapi lingkungannya.

Teori dasar tentang stress dapat disimpulkan ke dalam tiga variable pokok, yaitu sebagai berikut: (Ray wooll'e dan windy Dryden. 1998:530-532; James W. Greenvvood, III \& James W.Greenwood j r., 1979:30)

1. Variabel stimulus atau engineering approach (pendekatan kerekayasaan) yang mengkonsepsikan stress sebagai suatu stimulus atau tuntutan yang mengancam (berbahaya), yaitu tekanan dari luar terhadap individu yang dapat menyebabkan sakit (mengganggu kesehatan). Dalam model ini, stress dapat juga disebabkan oleh stimulasi ekternal baik sedikit maupun banyak.

2. Variabel REspon, atau physinlogiral approachf pendekatan fisiologis) yang didasarkan kepada model triphasc dari hans selye.Dia lahir di Vienna yang menghabiskan karir propesionalnya di universitas McGill di montreal. Dia mengembangkan konsep yang lebih spesifik tentang reaksi manusia terhadap stressor, yang dia namakan GAS (General Adaptation syndroine) yaitu mekanisme respon tipikal tubuh dalam merespon rasa sakit,ancaman atau stressor lainnya. GAS terdiri dari tiga tahap yaitu:

a) Reaksi alarm,yang terjadi ketika organisme merasakan adanya ancaman, yang kemudian merespon dengan fight atau flight,

b) Resistance, yang terjadi apabila stress itu berkelanjutan, disini terjadi perubahan fisiologis yang melakukan keseimbangan sebagai upaya mengatasi ancaman .

c) Exhaustion, yang terjadi jika stress terus berkelanjutan di atas periode waktu tertentu,sehingga organisme mengalami sakit (menerut selye, organisme memiliki keterbatasan untuk melawan (fight) stress. Dia mendefinisikan stress sebagai "The State which manifests it self by the GAS" atau" The nonspesifik response $u f$ the budy to any demand made upon it. Selanjutnya dia mengemukakan bahwa stress merupakan hal yang esensial bagi kehidupan. Tanpa stress tidak ada kehidupan,namun kegagalan dalam mereaksi stressor merupakan tanda kematian.

3. Variabel Interaktif, yang meliputi dua teori yaitu:

a) Teori Interaksional. Teori yang memfokuskan pembahasan kepada aspek-aspek (1) keterkaitan antara individu dengan lingkungannya, dan (2) hakikat hubungan antara tuntutan pekerjaan dengan kebebasan mengambil keputusan. Namun penelitian terakhir mengindikasikan bahwa terdapat bukti yang lemah yang mendukung hubungan antara tuntutan- tuntutan spesifik dengan sakit.

b) Teori transaksional. Yang memfokuskan pembahasannya kepada aspek-aspek kognitif dan apektif individu dalam berinteraksi dengan lingkungan, serta gaya- 
gaya "coping" yang dilakukannya. Salah satu teori yang terkenal dari teori transaksional ini adalah teori dari Lazarus dan folkmanf 1984). Mereka mendifinisikan stress sebagai "hasil (akibat) dari ketidakseimbangan antara tuntutan dan kemampuan". Pengertian ini mengimplikasikan bahwa apabila tuntutan itu lebih besar dari kemampuan yang dimiliki individu, maka dia akan mengalami stress. Tetapi sebaliknya, apabila kemampuan individu lebih besar dari tuntutan,atau dia memiliki kesanggupan untuk mengatasi ancaman yang dihadapi, maka dia menilai tuntutan atau ancaman itu sebagai tantangan,sehingga tuntutan itu tidak menyebabkan stress.

Terkait dengan variabel respon terhadap stress, Walter Cannon sekitar tahun 1932 mengemukakan bahwa manusia merespon peristiwa stress dengan fisik maupun psikis untuk mempersiapkan diriya, apakah melawan,mengatasi atau menghindar,melarikan diri dari stress (fight or fliglit response). Selanjutnya dia mengatakan bahwaketika individu mempersepsi adanya ancaman, maka tubuhnya secara cepat mereaksinya melalui system saraf simpatetik dan system endoktrin. Respon atau reaksi tubuh itu memobilisasi organisme untuk menyerang atau menghindari ancaman tersebut. Cannon berpendapat bahwa di satu sisi, respon atau reaksi fight or flight itu merupakan usaha organisme untuk beradaptasi,sebab melalui reaksi itu organisme dapat merespon ancaman secara cepat. Di sisi lain, stress itu dapat merugikan organisme, karena mengganggu fungsi emosi dan fisik,serta dapat menyebabkan masalah kesehatan setiap saat. Apabila stress tersebut terus menerus terjadi,berarti individu akan mengalami masalah kesehatan selamanya.

Menurut Dadang Hawari (1997:44-45) istilah stress tidak dapat dipisahkan dari Distress dan Depresi, karena satu nama lainnya saling terkait. Stress merupakan "reaksi fisik terhadap permasalahan kehidupan yang dialaminya: dan apabila fungsi organtubuh sampai terganggu dinamakan Distress. Sedangkan Depresi merupakan reaksi kejiwaan terhadap stressor yang dialaminya. Dalam banyak hal manusia akan cukup cepat untuk pulih kembali dari pengaruh-pengaruh pengalaman stress. Manusia mempunyai suplai yang baik dan energy penyesuaian diri untuk dipakai dan diisi kembali bila mana perlu.Stress dapat diartikan sebagai "respon(reaksi) fisik dan psikis, yang berupa perasaan tidak enak, tidak nyaman, atau tertekan terhadap tekanan atau tuntutan yang dihadapi. Diartikan juga reaksi fisik yang dirasakannya tidak nyaman sebai dampak dari persepsi yang kurang tepat terhadap sesuatu yang mengancam dirinya, merusak harga dirinya, menggagalkan keinginannya atau kebutuhannya.

\section{Gejala-Gejala Stress}

Beberapa gejala-gejala stres yang biasanya berlangsung terus menerus dan lebih dari dua minggu antara lain:

1. Hilang minat terhadap kegiatan yang disenangi.

2. Hilang selera makan, yang berujung pada penurunan berat badan.

3. Terlihat lelah, atau kekurangan energi. 
4. Memiliki perasaan tidak berharga dan tidak memiliki harapan.

5. Rasa bersalah yang tidak pada tempatnya.

6. Tidak mampu berkonsentrasi dan berpikir jernih.

7. Melankolik (rasa sedih berlebihan) yang biasanya disertai bangun pagi terlambat dua jam dari biasanya, rasa tidak berdaya di pagi hari dan bergerak lebih lamban.

8. Pusing atau sakit perut.

9. Mempunyai keinginan atau harapan untuk mati, bahkan bunuh diri.

Stres menampakkan diri dengan berbagai cara. Sebagai contoh, seorang individu yang sedang stres berat mungkin mengalami tekanan darah tinggi, sariawan, jadi mudah jengkel, sulit membuat keputusan yang bersifat rutin, kehilangan selera makan, rentan terhadap kecelakaan, dan sebagainya. Akibat stres dapat dikelompokkan dalam tiga kategori umum: gejala fisiologis, gejala psikologis, dan gejala perilaku. Pengaruh gejala stres biasanya berupa gejala fisiologis. Terdapat riset yang menyimpulkan bahwa stres dapat menciptakan perubahan dalam metabolisme, meningkatkan detak jantung dan tarikan napas, menaikkan tekanan darah, menimbulkan sakit kepala, dan memicu serangan jantung. Stres yang berkaitan dengan pekerjaan dpat menyebabkan ketidakpuasan terkait dengan pekerjaan. Ketidakpuasan adalah efek psikologis sederhana tetapi paling nyata dari stres. Namun stres juga muncul dalam beberapa kondisi psikologis lain, misalnya, ketegangan, kecemasan, kejengkelan, kejenuhan, dan sikap yang suka menunda-nunda pekerjaan.

\section{Penyebab Stress}

1. Faktor lingkungan

Selain memengaruhi desain struktur sebuah organisasi, ketidakpastian lingkungan juga memengaruhi tingkat stres para karvawan dan organisasi. Perubahan dalam siklus bisnis menciptakan ketidakpastian ekonomi, misalnya, ketika kelangsungan pekerjaan terancam maka seseorang mulai khawatir ekonomi akan memburuk.

2. Faktor organisasi

Banyak faktor di dalam organisasi yang dapat menyebabkan stres. Tekanan untuk menghindari kesalahaan atau menyelesaikan tugas dalam waktu yang mepet, beban kerja yang berlebihan, atasan yang selalu menuntut dan tidak peka, dan rekan kerja yang tidak menyenangkan adalah beberapa di antaranya. Hal ini dapat mengelompokkan faktor-faktor ini menjadi tuntutan tugas, peran, dan antarpribadi.

Adapun faktor-faktor penyebab stres kerja (stressor) karyawan adalah sebagai berikut.

a. Stres kerja yang dialami seseorang dipengaruhi oleh faktor penyebab stres baik yang berasal dari dalam pekerjaan maupun dari luar pekerjaan. Faktor penyebab stres kerja yang dibahas dalam penelitian ini hanya faktor organisasional, yakni faktor yang berasal dari dalam pekerjaan yang mencakup tuntutan tugas, tuntutan 
peran, tuntutan hubungan antarpribadi, struktur organisasi, kepemimpinan organisasi, dan tahap hidup organisasi.

b. Tuntutan tugas adalah faktor yang terkait dengan pekerjaan seseorang. Tuntutan tersebut meliputi desain pekerjaan individual, kondisi kerja, dan tata letak fisik pekeijaan. Sebagai contoh, bekerja di ruangan yang terlalu sesak atau di lokasi yang selalu terganggu oleh suara bising dapat meningkatkan kecemasan dan stres. Dengan semakin pentingnya layanan pelanggan, pekerjaan yang menuntut faktor emosional bisa menjadi sumber stres.

c. Tuntutan peran berkaitan dengan tekanan yang diberikan kepada seseorang sebagai fungsi dari peran tertentu yang dimainkannya dalam organisasi. Konflik peran menciptukan ekspektasi yang mungkin sulit untuk diselesaikan atau dipenuhi.

d. Tuntutan antarpribadi adalah tekanan yang dieiptakan oleh karyawan. Tidak adanya dukungan dari kolega dan hubungan antarpribadi yang buruk dapat meyebabkan stres, terutama di antara para karyawan yang memiliki kebutuhan sosial yang tinggi.

\section{Faktor pribadi}

Faktor-faktor pribadi terdiri dari masalah keluarga, masalah ekonomi pribadi, serta kepribadian dan karakter yang melekat dalam diri seseorang. Survei nasional secara konsisten menunjukkan bahwa orang sangat mementingkan hubungan keluarga dan pribadi, berbagai kesulitan dalam hidup perkawinan, retaknya hubungan, dan kesulitan masalah disiplin dengan anak-anak adalah beberapa contoh masalah hubungan yang menciptakan stres.

Masalah ekonomi karena pola hidup yang lebih besar pasak daripada tiang adalah kendala pribadi lain yang menciptakan stres bagi karyawan dan mengganggu konsentrasi kerja karyawan. Studi terhadap tiga organisasi yang berbeda menunjukkan bahwa gejala-gejala stres yang dilaporkan sebelum memulai pekerjaan sebagian besar merupakan varians dari berbagai gejala stres yang dilaporkan sembilan bulan kemudian. Hal ini membawa para peneliti pada kesimpulan bahwa sebagian orang memiliki kecenderungan kecenderungan inheren untuk mengaksentuasi aspek-aspek negatif dunia secara umum. Jika kesimpulan ini benar, faktor individual yang secara signifikan memengaruhi stres adalah sifat dasar seseorang. Artinya, gejala stres yang diekspresikan pada pekerjaan bisa jadi sebenarnya berasal dari kepribadian orang itu.

\section{Trauma}

Trauma adalah cedera fisik atau emosional. Secara medis, "trauma" mengacu pada cedera serius atau kritis, luka, atau syok. Dalam psikiatri, "trauma" memiliki makna yang berbeda dan mengacu pada pengalaman emosional yang menyakitkan, menyedihkan, atau mengejutkan, yang sering menghasilkan efek mental dan fisik berkelanjutan.

Trauma emosional dan psikologis adalah akibat peristiwa penuh tekanan yang luar biasa yang menggoyahkan rasa aman diri anda, membuat anda tidak berdaya dan rentan 
terhadap dunia yang berbahaya. Semakin takut dan tidak berdaya yang anda rasakan, kemungkinan semakin anda menjadi traumatis.

Peristiwa penuh tekanan yang memungkinkan menjadi traumatis jika :

1. Terjadinya secara tiba-tiba

2. Anda tidak siap dengan kejadiannya

3. Anda merasa tidak berdaya untuk mencegahnya

4. Terjadi berulang-ulang

5. Dilakukan seseorang dengan sengaja

Setiap manusia memiliki pertahanan tubuh yang berbeda. Bahkan, terkadang bahan yang digunakan untuk membangun tubuh kita juga berbeda, misalnya pada penyakit osteoporosis. Apabila terjadi benturan-benturan kecil sekalipun, akan mengakibatkan fraktur pada penyakit ini. Dan, benturan keras yang dapat merusak tubuh inilah yang sering disebut dengan trauma. Trauma dibagi atas tujuh bentuk, yaitu : trauma mekanik, trauma panas, trauma bahan kimia, trauma listrik, trauma radiasi, trauma biologis dan trauma emosi. Berikut ini adalah penjelasannya.

1) Trauma Mekanik

Salah satu ciri yang paling khas dalam trauma mekanik adalah terjadinya fraktur tulang yang patah. Apabila seseorangmempertahankan dirinya terhadap suatu pukulan atau benturan, kemungkinan besar os ulnaris nya akan patah. Tulang radius juga akan patah apabila seseorang yang jatuh, menopang badan hanya dengan salah satu tangannya saja. Dan, masih banyak lagi kejadian lain yang bisa menyebabkan fraktur tulang kita parah. Jika kita melakukan goresan pada tangan dengan menggunakan kunci atau alat tajam lain secara cepat, maka rasa nyeri yang timbul pada tangan bukan hanya satu, namun dua jenis nyeri. Selama goresan berlangsung, terdapat nyeri ringan yang langsung dirasakan dan dapat dilokalisir secara rapat. Kemudian, selama kira-kira setengah menit, keaadaan akan tenang kembali. Setelah itu. akan menyusul suatu nyeri yang sangat berbeda, yaitu nyeri bakar yang terus menerus dan sangat mengganggu. Nyeri yang juga dapat ditemukan pada berbagai penyakit inilah yang sering disebut trauma mekanik. Setelah beberapa menit, pada bekas goresan tadi terlihat garis merah. Inilah yang dinamakan peradangan. Peradangan di sekitar goresan ini akan terasa panas saat diraba. Setelah itu, akan terjadi pembengkakan yang pucat di tangan tempat goresan tersebut.

2) Trauma Panas

Trauma panas dapat terjadi karena adanya jaringan yang terbakar secara langsung atau membeku, akibat tekanan suhu yang terlalu dingin. Bisa juga secara berharap seluruh tubuh mendapatkan panas yang berlebihan atau karena dingin yang terlalu rendah.

3) Trauma Bahan kimia

Trauma bahan kimia dapat terjadi karena memakan racun, misalnya fosfor kucing yang terdapat dalam korek api zaman dahulu. 
4) Trauma Listrik

Trauma listrik ini merupakan bentuk syok akibat tersengal bentuk syok akibat tersengat Hstirik bertegangan tinggi. Trauma seperti ini bisa merusak jantung, otak, bahkan sering mengakibatkan kematian

5) Trauma Radiasi

Trauma radiasi dapat terjadi akibat hujan debu radioaktif yang berasal dari letusan bom. Bahkan, cahaya matahari pun dapat menyebabkan trauma (sunburn) ini.

6) Trauma Biologi

Trauma biologi dapat disebabkan oleh bakteri, virus, parasit, malaria, gigitan ular dan segala gangguan dari makhluk biologi lainnya.

7) Trauma Emosi

Trauma emosi biasanya disebabkan oleh teman sendiri atau sesama manusia.

\section{Gejala-Gejala Trauma}

Berikut merupakan gejala-gejala trauma yaitu:

1. Mengarahkan kesulitan mereka kepada diri sendiri, menjadi pendiam, tidak mau bergaul dengan teman-teman mereka.

2. Kelakuan mereka seperti anak kecil lagi (ngompol di tempat tidur, mengisap jempol, mimpi ketakutan), atau bicara bergagap.

3. Menjadi sepat marah, aggressive, berkelakuan nakal, berkelahi.

4. Tidak dapat tidur, takut tidur sendiri, tidak mau ditinggal sendirian meskipun untuk waktu yang singkat saja.

5. Mencari "tempat aman" di tempat mereka berada. Kadang-kadang mau tidur di lantai, tidak mau tidur di tempat tidur, karena takut kalau tidur nyenyak tidak tahu kalau bahaya datang.

6. Ketakutan kalau mendengar, melihat, atau mencium sesuatu yang mirip seperti waktu kejadian trauma berlangsung. Bunyi mobil kadang- kadang mengingatkan si anak kepada bunyi tembakan yang membunuh seseorang. Untuk seorang anak, mendengar anjingnya jalan turun dari tangga, seperti ayahnya jatuh dari tangga dan mati.

7. Menjadi waspada terus-selalu melihat-lihat sekeliling karena takut ada bahaya.

8. Berlaku seperti tidak takut karena sesuatu dan kepada siapapun juga. Kalau ada bahaya mereka berlaku tidak wajar, sambil berkata mereka tidak takut pada apapun juga.

9. Lupa kecakapan yang baru saja dipelajari.

10. Berkata-kata mau membalas dendam.

11. Sakit kepala, sakit perut, cepat capai dan sakit-sakit yang sebelumnya tidak ada.

12. Sering mengalami kecelakaan karena mengambil risiko yang berbahaya, menempatkan diri sendiri di tempat-tempat bahaya, men- sandiwarakan kejadian trauma sekali lagi seperti korban (victim) atau tokoh.

13. Kesulitan-kesulitan di sekolah, nilai yang menurun, dan kesulitan konsentrasi. 
14. Menjadi pesimis, tidak ada harapan masa depan, kehilangan keinginan untuk survive, bermain, menikmati hidup.

15. Minum obat narkotik atau ikut gerakan-gerakan yang melawan kebudayaan (counler culture movement) teristimewa bagi anak-anak yang lebih tua.

\section{Penyebab Trauma.}

Penyebab dari trauma meliputi 2 faktor yaitu:

1. Faktor internal (psikologis)

Bentuk gangguan dan kekacauan fungsi mental, atau kesehatan mental yang disebabkan oleh kegagalan bereaksinya mekanisme adaptasi dari fungsi-fungsi kejiwaan terhadap stimuli ekstern dan ketegangan-ketegangan, sehingga muncul gangguan fungsi atau gangguan struktur dari satu bagian, satu organ, atau sistem kejiwaan/mental. Merupakan totalitas kesatuan ekspresi proses kejiwaan/mental yang patologis terhadap stimuli sosial dikombinasikan dengan faktor-faktor kausatif sekunder lainnya (patologi adalah ilmu tentang penyakit).

Secara sederhana, trauma dapat dirumuskan sebagai gangguan kejiwaan akibat ketidakmampuan seseorang mengatasi persoalan hidup yang harus dijalaninya, sehingga yang bersangkutan bertingkah secara kurang wajar.

Sebab-sebab timbulnya trauma yaitu:

a. Kepribadian yang lemah atau kurang percaya diri sehingga menyebabkan yang bersangkutan merasa rendah diri, ( orang- orang melankolis)

b. Terjadinya konflik sosial budaya akibat dari adanya norma yang berbeda antara dirinya dengan lingkungan masyarakat,

c. Pemahaman yang salah sehingga memberikan reaksi berlebihan terhadap kehidupan sosial (overacting) dan juga sebaliknya terlalu rendah diri (underacting).

Proses-proses yang diambil oleh sesorang dalam menghadapii kekalutan mental, sehingga mendorongnya kearah :

a. Positif, bila trauma (luka jiwa) yang dialami seseorang, akan disikapi untuk mengambil hikmah dari kesulitan yang dihadapinya, setelah mencari jalan keluar maksimal, tetapi belum mendapatkannya tetapi dikembalikan kepada sang pencipta yaitu Allah SWT, dan bertekad untuk tidak terulang kembali dilain waktu.

b. Negatif, bila trauma yang dialami tidak dapat dihilangkan, sehingga yang bersangkutan mengalami frustasi, yaitu tekanan batin akibat tidak tercapainya apa yang dicita-citakan. 


\section{Contohnya:}

a. Agresi: Meluapkan rasa emosi yang tidak terkendali dan cenderung melakukan tindakan sadis yang dapat mambahayakan orang lain.

b. Regresi: Pola reaksi yang primitif atau kekanak-kanakan, (menjerit, menangis dll).

c. Fiksasi: Pembatasan pada satu pola yang sama (membisu, memukul dada sendiri dll).

d. Proyeksi: Melemparkan atau memproyeksikan sikap-sikap sendiri yang negatif pada orang lain.

e. Indentifikasi: Menyamakan diri dengan sesorang yang sukses dalam imajinasi, (kecantikan, dengan bintang film .dll)

f. Narsisme self love: Merasa dirinya lebih dari orang lain.

g. Autisme: Menutup diri dari dunia luar dan tidak puas dengan pantasinya sendiri.

2. Faktor eksternal (fisik)

a. Faktor orang tua dalam bersosialisasi dalam kehidupan keluarga, terjadinya penganiyayaan yang menjadikan luka atau trauma tisik,

b. Kejahatan atau perbuatan yang tidak bertanggung jawab yang mengakibatkan trauma Fisik dalam bentuk luka pada badan dan organ pada tubuh korban.

\section{Frustasi/Frustrasi}

Definisi Frustrasi berasal dari bahasa Latin frustratio, yaitu hambatan, kegagalan, rintangan. Definisi Frustasi menurut Katz \& Lehner frustasi merupakan rintangan erhadap dorongan atau kebutuhan, dorongan manusia yang banyak sekali jumlahnya, selayaknyalah bahwa semua itu tidak dapt dipenuhi secara bersama-sama, ada pula yang tidak dapat di penuhi secara wajar.

Kebutuhan manusia atau dorongan manusia yangbersifat fundamental itu menimbulkan ia bertingkah laku atau berbuat dalam bentuk untuk mencapai tujuan seing mendapat halangan atau kekecewaan. Bahwa ia dapat dikatakan mengalami frustasi sangat tergantung pada tanggapan masing- masing terhadap situasi atau keadaan dan cara mengekspresikan frustasi itu. Misalnya suatu keadaan atau situasi membuat dua orang sama-sama mengalami frustasi, sebenarnya mereka mempunyai dasar pengalaman yang berbeda sehingga tingkah laku mereka selanjutnyapun akan berbeda. Perasaan-perasaan frustasi itu bermacam-macam kualitas dan kuantitasnya. Jarak dan dalamnya suatu keputusasaan, kemarahan ataupun kasih sayang kadang-kadang merupakan peristiwa yang menyenangkan serta membantu memberi kekuatan dan memberikan rangsangan.

\section{Gejala Frustasi/Frustrasi}

Frustasi atau depresi sebenarnya dapat dicegah dan diselesaikan dengan mudah melalui beberapa tips berikut. Namun, sebelum anda mengetahui cara mencegah dan mengatasi frustrasi anda, sebaiknya anda mengetahui beberapa gejala symptom postpartum depression. Gejala-gejala depresi tersebut antara lain tidak dapat tidur dengan 
nyenyak atau mengalami gangguan tidur (insomnia), mudah marah, segala macam hiburan tidak dapat menghibur diri sendiri, merasa benci terhadap diri sendiri karena berbagai alasan yang tidak masuk akal dan mudah menangis. Cara mengatasi symptom post-partum depression adalah dengan tidak memaksakan diri untuk melakukan semua pekerjaan di rumah, . Sadarilah bahwa semua kegiatan tersebut tidak dapat anda lakukan sendiri tanpa bantuan orang lain.

Adapun gejala-gejala frustasi yang berkaitan dengan pekerjaan yaitu meliputi:

1. Meremehkan pekerjaan orang lain tanpa bisa membuktikan memang bisa dari pekerjaan yang diremehkan tersebut.

2. Meremahkan keahlian orang lain tanpa bisa membuktikan memang benar-benar ahli dari orang yang di remehkan keahliannya.

3. Menggurusi orang lain di luar dari jobdesknya (terlalu sibuk usil sama orang lain) hingga dia terlupa untuk meninggkatkan diri yang sesuai dengan jobdesknya.

4. Terlalu mengasihi'diri sendiri sehingga tidak pernah ada jalan keluar dari semua masalah yang menimpanya.

\section{Penyebab Frustasi}

1. Frustasi lingkungan

Frustasi yang disebabkan oleh halangan atau rintangan yang terdapat dalam lingkungan.

2. Frustasi pribadi

Frustasi yang tumbuh dari ketidakpuasan seseorang dalam mencapai tujuan dengan perkataan lain frustasi pribadi ini terjadi karena adanya perbedaan antara tingkatan aspirasi dengan tingkatan kemampuannya.

3. Frustasi konflik

Frustasi yang disebabkan oleh konflik dari berbagai motif dalam diri seseorang dengan adanya motif saling bertentangan, maka pemuasan dari salah satu motif yang menyebabkan frustasi bagi motif yang lain. Diantaranya motif tersebut adalah:

a. Konflik mendekat-mendekat (memilih satu dari dua pilihan),

b. Konflik mendekat menjauh,

c. Konflik menjauh-jauh.

4. Tidak ada ilmu pengetahuan tentang hidup

Ilmu pengetahuan tentang kehidupan itu adalah ilmu yang paling penting di antara semua ilmu yang ada. Apabila seseorang tidak mempunyai ilmu ini, maka dia akan mudah mengalami kegundahan, kesedihan, kegelisahan yang panjang dalam kehidupannya, sulit untuk kembali bangkit apabila dia jatuh. Cobaan-cobaan dalam kehidupan seseorang yang tidak mempunyai ilmu ini akan membuatnya merasa sangat berat untuk menjalaninya yang bisa berakibat orang tersebut putus asa.

5. Terlalu Banyak Tekanan/Masalah Hidup

Tuntutan pendidikan yang tinggi, tuntutan suatu tugas pekerjaan yang berat, tuntutan untuk memenuhi kebutuhan hidup, tuntutan untuk mencapai suatu kehidupan yang terjamin, serta tuntutan dari keluarga terkadang hal itu bisa dengan mudah membuat 
orang stress. Tekanan yang sangat intens itu akan mempengaruhi orang yang lemah psikologisnya. Pikirannya tidak akan sanggup untuk menerima semua yang terjadi, sehingga semua masalah itu akan menjadi beban di dalam pikirannya tersebut. Akibatnya kefrustasianlah yang akan jadi temannya nanti.

\section{SIMPULAN}

Peran bimbingan konseling Islam sangat membantu sekali dalam memberikan motivasi dan pemecahan masalah untuk terus menjalani hidup dalam berbagai kondisi atau keadaan apapun. Dalam prosesnya, pelaksanaan bimbingan konseling terdapat faktorfaktor yang mempengaruhi berjalanannya proes konseling, meliputi faktor eksternal yang terdiri dari lingkungan fisik, tempat wawancara, penataan ruang, dan sebagainya; ada juga faktor internal yang terdiri dari pihak konseli yang harus termotivasi untuk mencari penyelesaian terhadap masalah yang sedang dihadapi. Dari permasalahan tersebut banyak sekali yang kejadian atau yang dirasakan oleh orang yang mempunyai masalah, dapat berupa, konflik, trauma, stress. dan frusatasi yang mengakibatkan terganggunya psikis dan psikologinya.

\section{DAFTAR PUSTAKA}

Achmad Mubarok, al-Irsyad al-Nals. (2000). Konseling Agama Teori dan kasus. Jakarta: Bina Rena Prawira.

HM. Arifin. (1996). Teori-Teori Konseling Agama. Jakarta: Gralindo.

Makmun Khairani. Psikologi Umum. Yogyakarta: Aswaja Pressindo.

HS, Siti Sundari. (2005). KesehatanMontal. Jakarta : Rineka Cipta.

Kaplan, Harold I., Benjamin, J., and Greb, Jack A. (1996). Sinopsis Psikiarti, Jilid I. (Diterjemahkan oeh Widjaja Kusuma). Jakarta: Binarupa Aksara.

Najati, Utsman M. (1997). Al-Quran dan Ilmu j'/n/a. Bandung: Pustaka.

Semiun, Yustinus. (2006). Kesehatan Mental I. Yogyakarta: Kanisius. . (2006). Kesehatan Mental 2. Yogyakarta: Kanisius. (2006). Kesehatan Mental 3. Yogyakarta: Kanisius.

Thohari Musnamar dkk. (hd). Dasar-Dasar Konseptual Bimbingan dan Konseling Islami. Yusuf, Syamsu. (2008). Teori Kepribadian. Bandung,: Rosda. 
126 | Julaeha - Peran Pembimbing Konseling ... 